\title{
Paleozoic Exotic Blocks of the Crimean Mountains: Stratigraphy and Origin
}

\author{
Vsevolod V. Yutsis ${ }^{*}$, Alexander N. Stafeev ${ }^{2}$, Tatiana V. Sukhanova ${ }^{2}$ \\ ${ }^{1}$ Applied Geosciences Department, Potosino Institute of Scientific Research and Technology, San Luis Potosí, \\ Mexico \\ ${ }^{2}$ Department of Dynamic Geology, Geological Faculty, M.V. Lomonosov Moscow State University, Moscow, \\ Russia \\ Email: ${ }^{*}$ vsevolod.yutsis@ipicyt.edu.mx
}

Received 14 June 2014; revised 10 July 2014; accepted 5 August 2014

Copyright (C) 2014 by authors and Scientific Research Publishing Inc.

This work is licensed under the Creative Commons Attribution International License (CC BY). http://creativecommons.org/licenses/by/4.0/

(c) (i) Open Access

\begin{abstract}
Based on numerous geological data obtained by the authors for several decades, the stratification of Permian and Carboniferous ancient and exotic blocks of Crimean Mountains is performed. The sequence of geological events that cause their origin is revealed. Carnian-Norian, Rhaetian-Hettangian and Early-Pliensbachian phases of collapse, sliding and burial of Paleozoic blocks are specified. Final stage (block re-deposition) is confined to the Toarcian and Aalenian ages. The data obtained allow re-interpreting the origin of ancient exotic blocks of the Crimea.
\end{abstract}

\section{Keywords}

Crimea, Paleozoic Blocks, Paleogeography, Stratigraphy

\section{Introduction}

Numerous Paleozoic exotic blocks known in the northern slope of the Crimean Mountains had attracted the attention of geologists for many decades. Packs with these blocks are a part of relatively shallow-water strata of Eschiordinsky Series, developed mainly in Lozovsky structural-facial zone (Figure 1). The blocks consist of shallow, mostly biogenic (foraminifera, crinoid, algae, etc.) limestone of Carboniferous, Permian, Triassic and Liassic age and are included in the Upper Triassic-Lower Bajocian sand and clay strata. It is revealed, that many blocks are associated to syn-depositional faults and quartz sandstone lenses. There are still debated questions of block provenance location and of a block wide age spectrum in separate olistostrome packs. The stages and mechanisms of exotic block re-deposition are underexplored. An important factor to solve these problems is

*Corresponding author. 


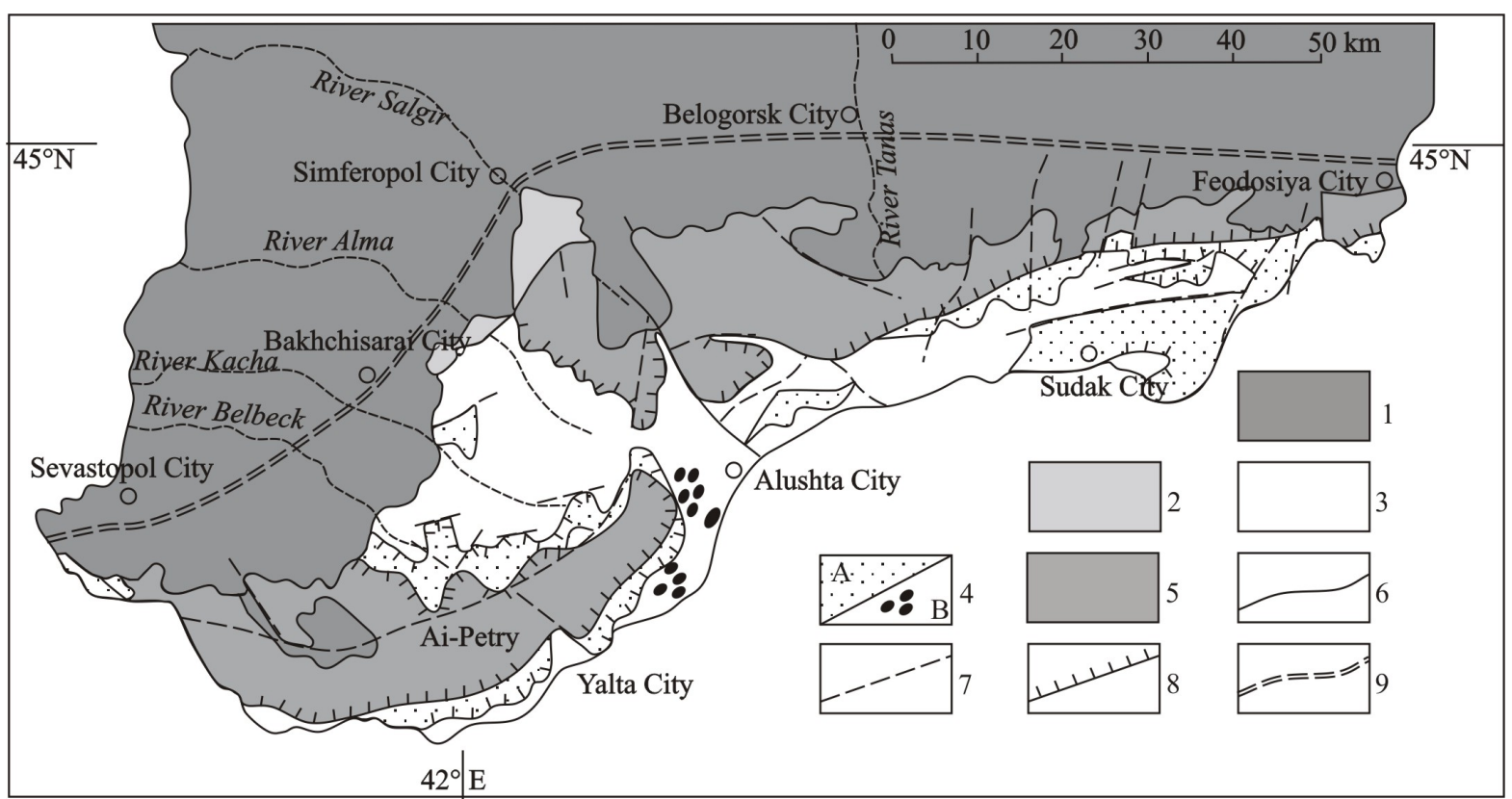

Figure 1. Tectonic sketch of Mountain Crimea: 1: platform cover of the Scythian plate; 2-5: structures of the Mountain Crimea: 2: Lozovsky structural-facial zone; 3, 4: Mountain Crimea zone: 3: Lower Triassic-Middle Jurassic unit (mainly Tavrichesky series), 4: middle unit, constructed by Middle-Upper Jurassic Formations (A: stratified sediments of the Eschiordinsky, Karadagsky and Sudaksky series, B: Middle Jurassic intrusions), 5: upper unit, represented by Tithonian-Bajocian Yailinsky series; 6: base of the sedimentary cover; 7: sub-vertical cuts, normal, reverse and strike-slip faults; 8: thrusts and nappes; 9: margin of the occurrence of the Mountain Crimea structural complex below platform cover [1].

the creation of a unified stratigraphic scheme in which olistostrome complexes could bind to consequent series of tectonic, volcanic, sedimentary and climatic conditions and events. The solution to this problem would allow using the blocky strata as marker horizons.

\section{Paleozoic Blocks Geology}

Carboniferous and Permian rocks are exposed only in the Crimea in the form of limestone blocks, which lie among the clastic sediments of the younger age groups-from Carnian to Bajocian [2]. The largest Carboniferous block having size of 24 by 18 meters and a height of $6 \mathrm{~m}$ is located on the right bank of Bodrak River near the Trudoljubovka village (Figure 2). Small Carboniferous blocks are located on both slopes of the Salgir river valley to the south of Simferopol City, in an area of Lozovoye village. The biggest Permian block called Dzhien-Sofu is located on the right bank of the Simferopol water reservoir; its dimensions are 100 by $70 \mathrm{~m}$. Another big Permian block (Kichkchi-Bournu) lies in the Martha river valley, $5 \mathrm{~km}$ upstream from its confluence with the river Kacha, a right tributary in $1 \mathrm{~km}$ above its mouth. Apparent block sizes are $50 \times 50 \times 15 \mathrm{~m}$. Smaller Permian blocks are found in the right side of the Bodrak river valley, on the left bank of the river Alma, in the valleys of the Boljshoi and Malyi Salgir. Upper Paleozoic rocks occur in the form of cobble, enclosed in younger Liassic deposits of the northern and southern slopes of the Crimean Mountains [2].

Paleozoic blocks of the northern slope of the Crimean Mountains stacked shallow-water organogenic gray and light-gray limestone, containing a variety of fusulinids, ammonoids, brachiopods, trilobites, rarer bivalves and gastropods; sometimes algae and crinoids are rock-forming [3]. The organic residual complex of Bodrak coal block sets its constituent species belonging to the lower Bashkirian stage; younger Paleozoic blocks belong to the Permian system [2] [4]. O. G. Tumanskaya [5], who studied in detail Upper Paleozoic deposits of Crimea, drew the conclusion of Crimean Permian block ammonite complex proximity to ammonoidea association, described by G. G. Gemmellaro [6] in the Permian fusuline limestone exotic blocks in the Sozio river valley in Sicily. Brachiopod fauna analysis and review of previously published paleontological data [3] indicates the Murghab age of the Upper Permian blocks of the Crimean Mountain and their coeval with blocks of Sicily [7].

Permian limestone blocks in the Salgir basin, west from the village of Eski-Orda, enclosed in shales and 


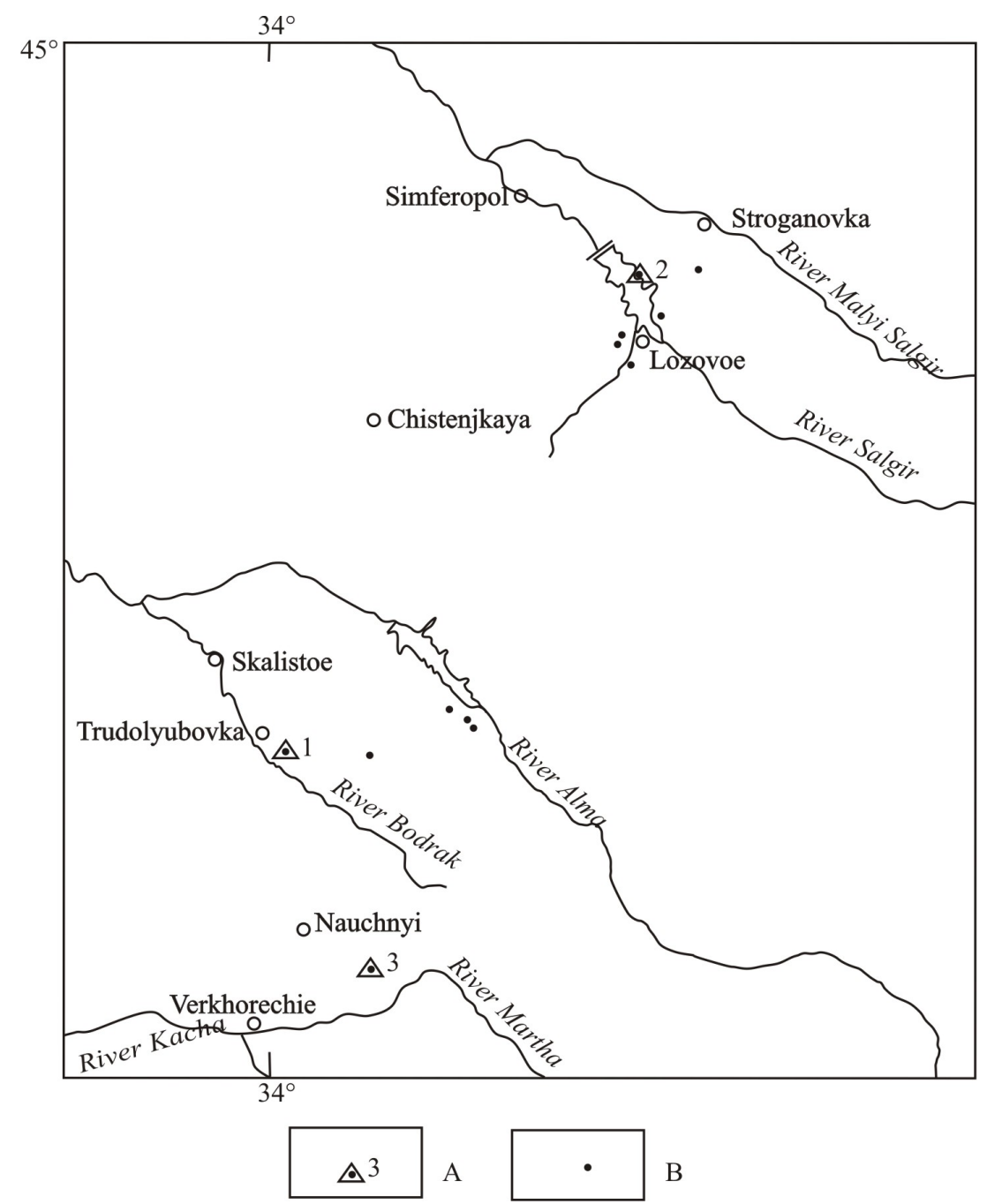

Figure 2. Location of the Crimean Paleozoic exotic blocks: A: megablocks (1: Bodraksky; 2: Dzhien-Sofu; 3: Martinsky (Kichkchi-Burnu)); B: small blocks.

sandstones with Triassic Halobia [8]. In other parts of the Salgir valley they occur in highly broken Taurida dumb shales. Dzhien-Sofu block is also surrounded by dumb Taurida shales. Carboniferous limestone blocks on the right bank of Salgir River to the northwest of Lozovoe's basalt quarries are located near the Triassic argillite band with Monotis caucasika Wit. [9]. Carboniferous block on Bodrak valley occurs in sandstone-clay strata containing Pliensbachian spore-pollen complex. The most enriched with the diverse fauna Permian Kichkchi-Burnu block on the right slope of the Martha valley probably lies in the Liassic sand-clay sequence, according to the downstream discovery of Pliensbachian crinoids [10]. Small individual Paleozoic blocks are found in Bithaksky conglomerates [4]. Also, except the Paleozoic blocks, Triassic and Liassic blocks quite often occur sometimes in the same places [11] [12]. The position in the cross-section of the limestone of the Upper Triassic and Liassic as lenses or blocks is almost always debatable. The biggest Upper Triassic block or bedrock limestone lens having length over $100 \mathrm{~m}$ is exposed on the left bank of Alma River, in $3 \mathrm{~km}$ to the north-west from Drovyanka village and in $1 \mathrm{~km}$ from the mouth of the ravine, which flows into the river Alma. According to a brachiopods fauna complex, limestones have Norian-Rhaetian age [8] [11].

\section{Stratigraphy}

Unified scheme compilation of the Triassic and Lower Jurassic stratigraphy is based on continuous (from Rhaetian to Bajocian) sequence of palynology assemblages (PA) obtained by authors from Alma and Bodrak river 
basins (Figure 3).

\subsection{Kurtsovskaya Formation, Carnian-Norian Stage}

Carnian-Norian flysch and flyschoid sediments of Lozovsky Zone contain no blocks, but often are in close proximity to them. Age is determined by the findings of Triassic Monotis and Halobia. With rare fauna and the same lithological type Carnian-Norian and Rhaetian Liassic flysch can be distinguished only by the absence of kaolinite in Carnian and Norian sequences, and usually higher kaolinite content in the overlying strata.

\subsection{Salgir Formation, Rhaetian-Sinemurian Stage}

Rhaetian and Hettangian palynology assemblages were specified in the Bodrak Basin cross-section containing re-deposited fragments of sandstone and mudstone with Monotis spp. [13] and thus, for the first time in the Crimea the Rhaetian and Hettangian age was set for clastic sediments [14]. Tops of the Rhaetian and Hettangian (150 - 200 meters) in the Bodrak Basin are stacked clay-sand deposits of small lakes, rivers or brackish lagoons.
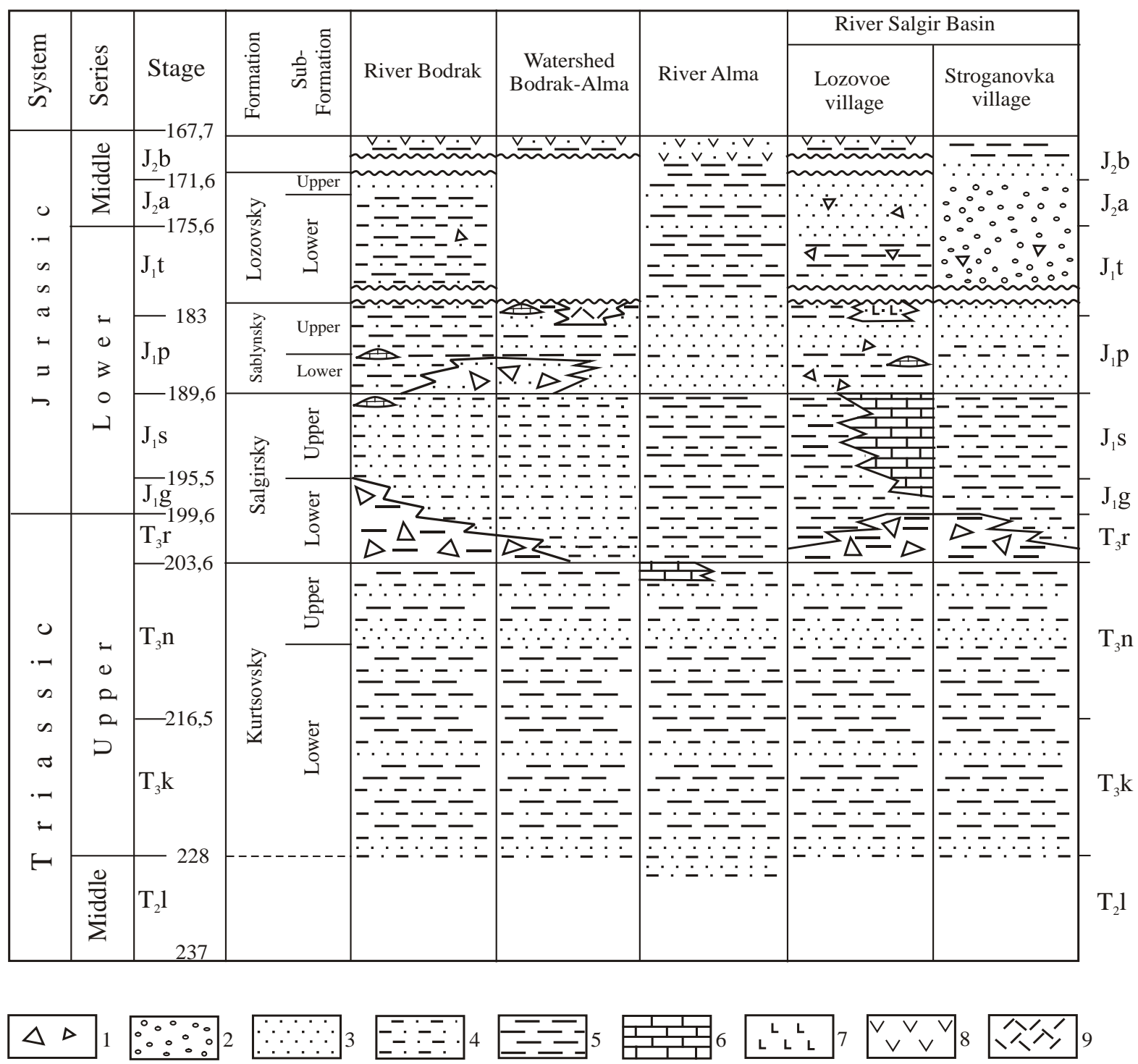

Figure 3. Chronostratigraphic chart of Triassic and Lower-Middle Jurassic sediments of the Lozovsky Zone. 1: blocks; 2: conglomerates; 3: sandstones; 4: siltstone; 5: claystone; 6: limestone; 7: doleritic and basaltic tuff; 8: andesite-basalts and tuffs; 9: rhyolites and tuffs. 
Crimean Rhaetian PA (Figure 3) characterized by forms of Ricciisporites tuberculatus Lundblad, Converrucosisporites luebbenensis Schulz, Limbosporites lundbladii Nilsson, Cingulizonales rhaeticus (Reinh.) Schulz and especially by dominating Ricciisporites tuberculatus, is close to Rhaetian complexes of Germany [15] and Western Pre-Caucasus [16].

Hettangian PA, highlighted in the section above, is set spectral presence of Auritulinasporites triclavis Nilsson, Auritulinasporites sp., Kyrtomisporites sp., Toroisporis nodosus Bona, Toroisporis sp. 1, Toroisporis sp. 2, Toroisporis sp. 3 Antonescu 1973, marked Hettangian sediments in Romania [17]. Deltoidosporajuncta (K.-M.) Singh presents in the Hettangian-Sinemurian and Sinemurian PA of Crimea; Cyclogranisporites sp. and Duplexisporites anagrammensis (K.-M.) Schug are found at the base of the Lias of Donbass [18].

Sinemurian PA of Crimea was identified from clays containing Upper Sinemurian zonal ammonites [19]. Sinemurian complex in comparison with Rhaetian and Hettangian is characterized by the absence of moss spores (Ricciisporites) and the occurrence of Toroisporis sp. 4, characteristic to Romanian Sinemurian [17]. Foveosporites minor Sem., Verrucosisporites orbiculatus (Krasn.) Sem., Sestrosporites sp., Tripartinavariabilis Mal., Deltoidosporajuncta (K.-M.) Singh, are indicated for Early-Middle Liassic complex of ammodiscus layers of Donbass [18].

\subsection{Sablynsky Formation, Pliensbachian-Lower Toarcian Stage}

The main feature of Sablynsky Formation is the presence of delta system quartz-sandstone lenses and packs in its cross-sections. In addition, as already noted, the upper sub-formation has a marking value for comparison of flysch cross-sections with relatively shallow-water basin-side facies. In Lozovsky zone the marking stratum contains Pliensbachian and Toarcian PA, and in the Crimean Mountain zone-Middle Liassic Aegoceras and Liparoceras [11], and Upper Liassic Dactilioceras [19].

Pliensbachian PA is obtained from the lower part of Sablynsky Formation. The presence of Toroisporiscras siangulatus (Balme) Barch., Leiotriletes karatauensis Timosh., Uvaesporitesscithicus Sem., Duplexisporites anagrammensis (K.-M.) Schug., Camptotriletes cerebriformis Naum. Et Jarosch., Phyllocladidites sp., and also the domination of Dipteridaceae spores and Cycadopites pollen grains, allow determining the Pliensbachian age. In favor of this affirmation shows the relatively low content of Classopollis sp., as their maximum in the Lias of the Crimean-Caucasian region is characteristic of the Toarcian. Close PA are described from SinemurianLower Pliensbachian sequences of North Caucasus [20].

Toarcian PA is subtracted from the uppers of Sablynsky Formation and the lowers of Lozovsky Formation. Its age is confirmed by the presence in the spectra of Dictyophyllidites harrisii Coup., D. spinescens Sem., Crassulina sp., Klukisporites sp., Gleicheniidites, Tripartinavariabilis Mal., Inaperturopollenites limbatus Sem. and other characteristic Toarcian forms, as well as a considerable content of pollen Classopollis, which distinguishes the Toarcian complex from other Liassic assemblages. The greatest similarity this PA has with the Toarcian assemblages of North Caucasus, dated by ammonites [20].

\subsection{Lozovsky Formation, Middle Toarcian-Lower Bajocian Stage}

Formation is composed of relatively shallow-water, argillaceous, sometimes flyschoid in the lower part, and clay-sand deposits in the top, interbedded with conglomerates. Lozovsky Formation began to form to the north of Lozovsky Zone of Bitaksky graben formed of coarse sand and conglomerate deposits in the basis.

In the Toarcian palynology spectra of Lozovsky Formation, unlike in Sablynsky one- the amount of dipteridaceae dramatically reduces, appear mosses, lycopsidas, caytoniales and acritarchs.

Aalenian PA substracted conventionally, due to the fact that climate and landscape changes at the turn of the Toarcian and Aalenian were smooth and quite weak, and not contributing to a sharp phytocenoses change. Aalenian presence in the Bodrak valley is confirmed by Leioceras sp. ammonite finding [21].

Bajocian PA, in comparison with Aalenian one contains new forms (genera Neoraistrickia, Apiculatisporites, Trachysporites). The content and diversity of Gleicheniaceae dramatically increases. This assemblage is compared with Bajocian PA of North Caucasus [20] and Eastern Pre-Caucasus [22].

\section{Paleogeography}

\subsection{Carnian and Norianage Age}

Sedimentary supply of the South Crimean Basin in Carnian and Norian age was managed through the flow of 
the North-Crimean Basin in which the roughest material was picked up. Runoff occurred through the transversal Nikolaev-Bakhchisarai trough of NW-trending. Abundant kaolinite (up to 45\%) appears in Rhaetian and Liassic deposits, due to arid-humid climate change in the late Norian age. At the turn of Norian and Rhaetian ages, in Salgir folding phase [23] [24] the bottom of the flysch basin had differential movement, and along its northern side the relatively shallow Lozovsky trough (up to $15 \mathrm{~km}$ wide) stood apart, bounded on the south with Lozovsky fault and separated from deep-water basin with the chain of horst-anticlinal uplifts.

\subsection{Rhaetian-Sinemurian Age}

Salgirsky Formation formed at the expense of local provenance, mainly due to landslide denudation of growing Rhaetian uplifts at the bottom of the flysh basin. At the lower part of the Salgirsky Formation Norian landslide blocks with Monotis fauna are present. Creeping occurred towards both the Lozovsky Zone and the Mountain Crimea Zone in the areas of syn-sedimentary faults, which amplitude could reach $1 \mathrm{~km}$ [25]. Part of landslides transformed into turbidity flows that transported material in low-lying areas of the basin bottom. Probably dumb turbidities strata formed that way, overbuilding Norian flysch. In the Valley of Alma River the uppermost part of flysch containing no Monotis, A. I. Shalimov [26] relates to the Rhaetian age. Located at nearby Trudolyubovsky horst-anticline zone elevations [27], provided erosion, Carboniferous rocks were outcropped. Rhaetian, Hettangian and Sinemurian palynology assemblages in the Bodrak basin contain, respectively, $12 \%$, 20\% and 47\% of re-deposited Carboniferous and rare Triassic forms. Obviously, first exotic blocks (first Triassic, later-Permian and Carboniferous) appear in the Salgirsky Formation sequence. In our opinion, Salgirsky Formation in the lower part is composed of a thicknesses Rhaetian olistostrome complex, formed in Lozovsky Zone as a result of avalanche landslide denudation of uplifts of bottom parts of flysch basin. This process went up to the denudation of the Upper Paleozoic limestones, their collapse and subsequent slumping of these limestone blocks.

\subsection{Pliensbachian-Early Toarcian Age}

In the early Pliensbachian large river system Paleo-Don penetrates into Crimea through the waters of modern Azov Sea from the flowing Yeisky lake basin. It was formed in the conditions of regional left side slip movements that have also led to fragmentation of Lozovsky Zone in a system of small shear basins and associated uplifts. In one of these basins (Mender Basin) Bodrak exotic block of Carboniferous limestone occurs (Figure 4), probably re-deposited from Rhaetic-Sinemurian olistostromes. At the same time, a sharp deepening of Crimean Mountain depression and flysch accumulation is occurred. With some delay in time, at the end of Pliensbachian age the volcanic centers rise in shear zones on the Scythian platform (Yeisky trough, etc.) and in the Lozovsky Zone [28].

\subsection{Late Toarcian-Early Bajocian Age}

A new cycle of sedimentation occurs simultaneously with the North Lozovsky Zone of Bitaksky graben emplacement that begins to intercept (since its inception) coarse material carried by the river system and regulate, thus, solid stock in the South Crimean basin. Local sources of ablation appeared in Lozovsky Zone due to tectonic movements of Donetsk folding phase [9].

\section{Discussion}

The main specificity of Lozovsky Zone cross-section is in the presence of olistostromes with exotic inclusions in it at different levels, as well as a variety of breccia. Some researchers believe them to be tectonic formations and even consider the entire Lozovsky area as a tectonic mélange [29]. They are assumed to be large-scale highamplitude thrusts, removing Paleozoic blocks from depths of 8 - $10 \mathrm{~km}$ out of autochthon. Undoubtedly, some boulders and debris tectonically brecciaed near faults, and the Lozovsky Zone has a very complex geological structure at several sites, but sources of blocks may be at depths of $2-3 \mathrm{~km}$ according to geophysical data [25]. The horizontal distance from the buried bedrock flanges to the current block position is only sometimes hundreds of meters or a few kilometers. One of the most ancient, Carboniferous block in the Bodrak Basin does not bear traces of tectonic effects more significant than the host rocks. Some blocks of small size is not sharp-angled; possibly bearing traces of surface dissolution could be re-deposited from older secondary olistostromes.

For a number of blocks the orientation of their long axes is marked along the stretch and layering lenses of 


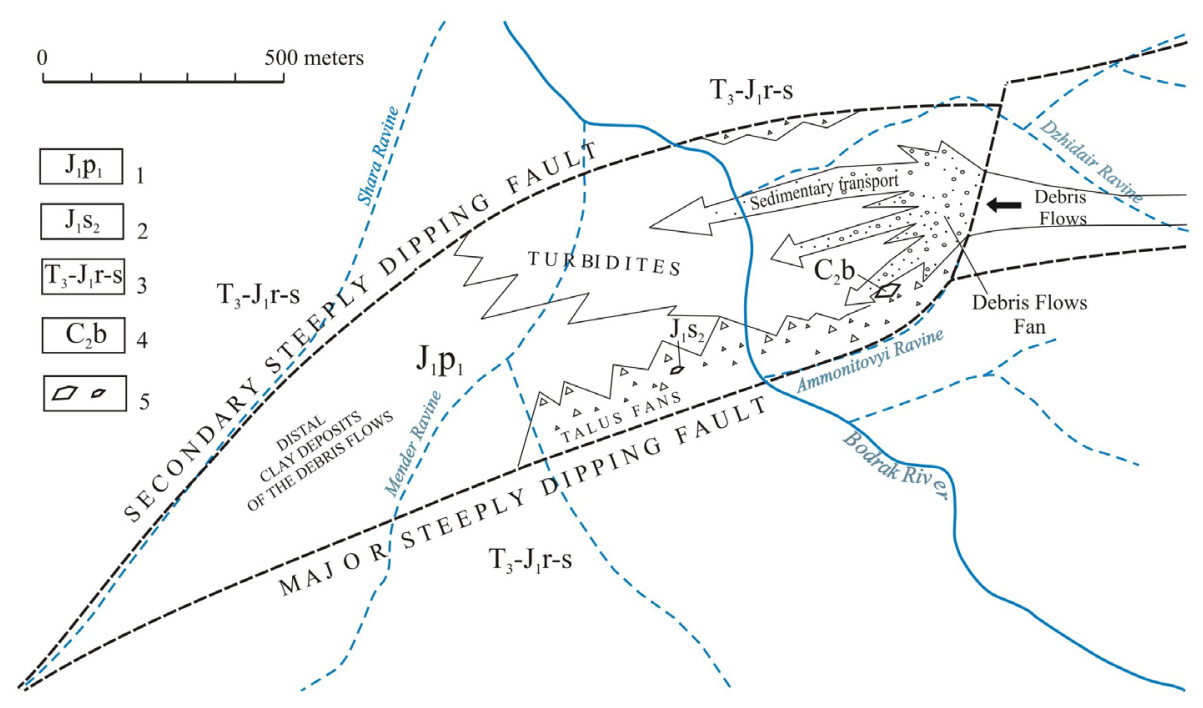

Figure 4. Lower Pliensbachian Mender basin: 1: Lower Jurassic System, Lower Pliensbachian Stage; 2: Lower Jurassic System, Upper Sinemurian Stage; 3: Upper Triassic System, Rhaetian Stage-Lower Jurassic Systems, Sinemurian Stage; 4: Upper Carboniferous (Pennsylvanian) System, Bashkirian Stage; 5: Exotic Blocks.

mature quartz sandstones and gravel-stones. This requires explanation, given the usual chaotic state of olistolith in the matrix. Some order can be explained by re-deposition of ancient olistostrome assemblage blocks in valley floors of younger river network, embedded in this complex. Such movement of blocks to the level of river flows, controlled by common basis erosion, creates the illusion of a certain affinity to the simpler surface, "cutting" a complex structure of olistostromes. By some researchers this surface is perceived as a breakdown surface.

Within the concept of underwater-landslide origin of blocks are also a number of unresolved issues.

Stratigraphy of the Triassic and Jurassic sediments of Lozovsky Zone is insufficiently developed and not standardized for the different facial zones. Besides the challenging facial pattern this is connected with the fact that not the only easily recognizable blocks slumped, but also a clay and sand-clay, sometimes very large fragments of cross-sections did. In the face of strong disturbance of these strata often remains the unresolved question of difference between the inclusions and matrix. For the same reason it is difficult to establish unambiguously the time of block sliding. It is necessary to identify the matrix and estimate its age, considering possible macro-fauna re-deposition not only for comprising crept fragments, but in the form of individual shells.

It remains unclear whether are olistostromes in the Crimean Mountains older than Rhaetian age, for example Ladinian-Carnian processes, which could be related to faults on the boards during the emplacement of the Triassic flysch basin.

Insufficiently explored is Trudolyubovskaya horst-anticlinal Zone, which divided Lozovsky and Crimean Mountains depressions in Rhaetian time and probably served as a major source of Paleozoic and Triassic shallow limestone blocks. On the surface its southern edge coincides with the Cretaceous quest ledges at the Second Ridge of Crimean Mountains.

It is required the further study of the putative link between exotic boulders well preservation and their occurrence in shear basins in which as blocks themselves and matrix enclosing them had not experienced significant tectonic processing during subsequent complex history with a number of phases of deformation. Limestone blocks are often low recrystallized and only in certain areas, and their enclosing matrix is presented by clays unlike mudstone of adjacent sections.

\section{Conclusions}

Horizons including Paleozoic and Triassic blocks formed at the beginning of major tectonic-sedimentary cycles 
(Rhaetian—Sinemurian, Pliensbachian—Lower Toarcian, Middle Toarcian—Lower Bajocian), with duration of 9 - 12 million years each. If volcanic rocks are present in the cross-sections of cycles, they lie above blocky horizons. Geographically volcanites are developed in the same place as the blocky horizons (Salgir Valley, Bodrak-Alma river Valley). Either lumps or volcanic centers are associated with the same faults, only to start volcanism time was needed to mature magmas at depth. For Liassic shifts of Crimea it is $5-7$ million years.

The main stage of rejection and primary slumping of Paleozoic and Triassic blocks accounted for Rhaetian age when at the bottom of the Tauride flysch basin, anticlinal zone along the northern edge of horst was originated, served as Paleozoic and Triassic block source after avalanche landslide denudation of its elevations,.

Most of currently denudated Paleozoic and Triassic blocks were re-deposited in the Early Pliensbachian (Figure 4). Re-deposited blocks lie in the composition of olistostromes in small shear basins or are being a gravitational accumulation (slope deposits, colluvium, and boulder pavement) of Pliensbachian river cuttings recognizable on layering lenses of mature quartz sandstones and gritstones. In the early Pliensbachian time separate blocks were probably rejected from indigenous Paleozoic ledges updated by shear tectonic movements. This type of block is Bodrak Carboniferous one. Olistostrome pack, in which it is contained, is underlain by Upper Sinemurian clay containing up to $47 \%$ re-deposited Carboniferous spores, more ancient than the block itself.

The block accumulation region in Middle Toarcian-Aalenian was located mainly to the North of Lozovsky Zone on the slopes of Bitaksky syn-sedimentary graben. Probably only Liassic blocks were rejected from indigenous ledges at this time. Paleozoic and Triassic small blocks and pebbles were re-deposited by their RhaetianLiassic olistostrome.

\section{Acknowledgements}

Many invaluable and significant paleontological and geological contributions provided by S. B. Smirnova, Z. I. Kazakova and V. Kosorukov (Moscow State University). The authors would like to thank participants of numerous fieldwork campaigns: students and researchers of the Moscow State University. Special thanks to staff of the Crimean campus of the Geological Faculty of MSU for the help in organization of geological studies. Finally we are grateful to anonymous referees for their useful comments.

\section{References}

[1] Mileev, V.S., Baraboshkin, E.Yu., Rozanov, S.B. and Rogov, M.A. (2006) Kimmerian and Alpine Tectonics of Mountain Crimea. Bulletin of Moscow Society of Naturalists, Geological Series, 81, 22-33.

[2] Mikhlukho-Maclay, A.D. and Muratov, M.V. (1958) On the Carboniferous and Permian Rocks of Mountain Crimea. High Education News Bulletin, Geology and Prospecting, 8, 30-35.

[3] Grunt, T.A. and Novikova, M.A. (2002) Late Permian Brachiopods of Mountain Crimea. Journal of Paleontology, 2, 32-38.

[4] Geology of the USSR (1969) Tome 8, Crimea, Part 1: Geological Structure. Nedra Publishing, Moscow.

[5] Tumanskaya, O.G. (1931) Permian-Carboniferous Sediments of Cimea. Part 1. Cephalopoda, Ammonoidea. Geolizdat Publishing, Moscow.

[6] Gemmellaro, G.G. (1887) La Fauna dei Calcari con Fusulinida della Valle del Fium Sosio nella Provincia di Palermo Brachiopoda. Giornale de Scienze Naturali ed Economiche de Palermo, 19, 1-106.

[7] Flugel, E. and Di Stefano, P. (1992) Microfacies and Depositional Structure of Allochthonous Carbonate Base of Slope Deposits: The Late Permian Pietra Salomone Megablock, Sosio Valley (Western Sicily). Facies, 25, 147-186. http://dx.doi.org/10.1007/BF02536758

[8] Moiseev, A.S. (1930) On the Geology of South-West Part of the Main Ridge of Crimean Mountains. Geolcom Publishing, Leningrad.

[9] Slavin, V.I. (1982) General Features of Geological Structure of the Joint Zone of Early and Late Kimmerides in the Basin of Salgir River in Crimea. Moscow University Geological Bulletin, 5, 68-79.

[10] Klikushin, V.G. (1988) On the Triassic and Early Jurassic Crinoidea of Crimea. Bulletin of Moscow Society of Naturalists, Geological Series, 63, 71-79.

[11] Muratov, M.V. (1959) On the Stratigraphy of Triassic and Lower Jurassic Sediments of Crimea. High Education News Bulletin, Geology and Prospecting, 11, 31-41.

[12] Kotlyar, G.V., Baud, A., Pronina, G.P., Zakharov, Y.G.D., Vuks, V.J., Nestell, M.K., Belyaeva, V. and Marcoux, J. (1999) Permian and Triassic Exotic Limestone Blocks of the Crimea. In: Crasquin-Soleau, S. and De Wever, P., Eds., 
Peri-Tethys: Stratigraphic Correlations 3, Geodiversitas, 21, 299-323.

[13] Smirnova, S.B., Stafeev, A.N., Sukhanova, T.V. and Rostovtseva, Yu.I. (2011) Hettangian and Sinemurian Palynology Assemblages of the Mountain Crimea. Proceedings of the 13th Russian Palynology Conference, Syktyvkar, 5-8 September 2011, 215-217.

[14] Stafeev, A., Smirnova, S., Rostovtseva, J., Sukhanova, T. and Kosorukov, V. (2013) Palynostratigraphy and Sedimentation Environments of the Eski-Orda Group of the Mountain Crimea. Proceedings of the 5th All-Russian Meeting “Jurassic System of Russia: Problems of Stratigraphy and Paleogeography”, Tyumen, 23-27 September 2013, 216218.

[15] Schulz, E. (1995) Palinologishe Untersuchungen des Marinen Mittelrhats im Greuzburger Graben bei Eisenach (WThuringen). Berliner Geowissenschaftliche Abhandlungen, 16, 427-437.

[16] Yaroshenko, O.P. (1999) Rhaetian Palynology Complexes of the Western Pre-Caucasus. In: Actual Problems of Palynology at the Turn of the Third Millennium, Moscow, 351-352.

[17] Antonescu, E. (1973) Quelques Donnees sur la Palynologie du Lias sous Facies de Gresten de Roumanie. Proceedings of the 3rd International Palynology Conference "Mezophyt Palynology", Moscow, 53-57.

[18] Semenova, E.V. (1970) Spores and Pollen of Jurassic Sediments and Boundary Layers of Donbass. Kiev.

[19] Kazakova, V.P. (1962) On the Lower Jurassic Stratigraphy of the Bodrak River Basin (Crimea). Bulletin of Moscow Society of Naturalists, Geological Series, 37, 36-51.

[20] Yaroshenko, O.P. (1965) Spores and Pollen Characteristic of Jurassic and Lower Cretaceous Sediments of North Caucasus and Their Stratigraphy Significance. Memories of Geological Institution of Academy of Sciences of the USSR, 117, 1-102.

[21] Permyakov, V.V. (1969) Stratigraphy of Jurassic Sediments of the UkrSSR. Crimea and Pre-Black Sea Depression. In: Stratigraphy of the Ukraine SSR, Tome 7, Jurassic, Kiev, 101-124.

[22] Stafeev, A.N., Smirnova, S.B., Gustchin, A.I., Kazakova, Z.I. and Koronovsky, N.V. (1993) Landscape Environments and Origin History of Middle Jurassic Sediments of the Eastern Pre-Caucasus. Moscow University Geological Bulletin, Series Geology, 1, 26-37.

[23] Moiseev, A.S. (1937) About Khersonian (Kimmerian) Orogeny and their Expression in Crimea. Memoires of the Society of Naturalists of Leningrad, 66, 6-33.

[24] Slavin, V.I. (1989) Geological Development of Crimea in Mesozoic. Moscow University Geological Bulletin, Series Geology, 6, 24-36.

[25] Khmelevskoy, V.K. and Kuzmina, E.N. (1967) On the Depth of Paleozoic Basement in the Mountain Crimea. Moscow University Geological Bulletin, Series Geology, 1, 119-122.

[26] Shalimov, A.I. (1960) New Data on the Stratigraphy of Upper Triassic and Lower Jurassic Formations of the SouthWest Part of Crimea Mountains. Doklady Earth Sciences of USSR, 132, 1407-1410.

[27] Plakhotny, L.G., Sidenko, O.G., Chir, N.M. and Abashin, A.A. (1988) On the Depth Tectonics of the Crimea Mountains Foothills and Exotic Limestone Blocks Origin. Geological Journal, 1, 120-127.

[28] Lebedinsky, V.I. and Shalimov, A.I. (1961) About Volcanic Activity during Early Jurassic Period in Mountain Crimea. Doklady Earth Science of the USSR, 140, 197-200.

[29] Yudin, V.V. (1993) Melange of Simferopol. Doklady Earth Science, 333, 250-252. 
Scientific Research Publishing (SCIRP) is one of the largest Open Access journal publishers. It is currently publishing more than 200 open access, online, peer-reviewed journals covering a wide range of academic disciplines. SCIRP serves the worldwide academic communities and contributes to the progress and application of science with its publication.

Other selected journals from SCIRP are listed as below. Submit your manuscript to us via either submit@scirp.org or Online Submission Portal.
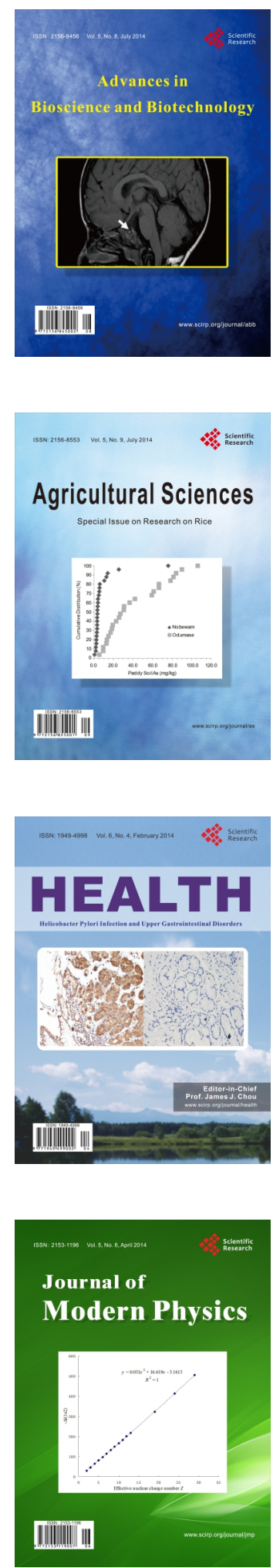
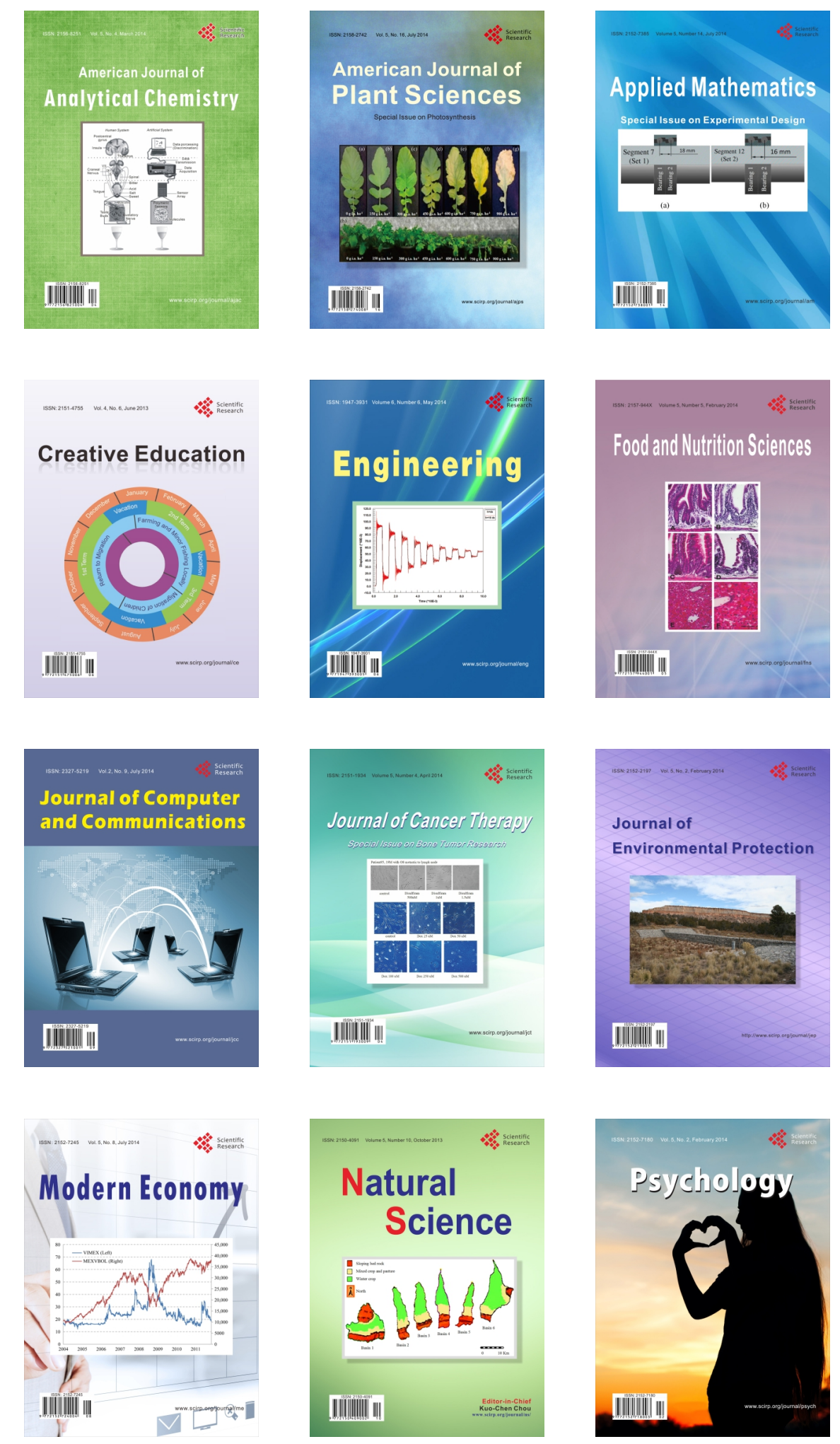